\title{
MOOCS AS A METHOD OF DISTANCE EDUCATION IN THE ARAB WORLD - A REVIEW PAPER
}

\author{
Raniah Samir Adham [r.s.a.adham@pgr.reading.ac.uk], Karsten Oster Lundqvist \\ [k.o.lundqvist@reading.ac.uk], School of Systems Engineering, University of Reading, United Kingdom
}

\begin{abstract}
Massive Open Online Courses (MOOCs) in the Arab World are still in their infancy. Many Arab countries are now starting to launch their MOOC platforms; however, there are only a few who have actually implemented such systems. This paper will explore online learning, in particular the rise of MOOCs around the world and their impact on the Arab World.

The purpose of this paper is to give a true picture of the development of the first MOOC platforms in the Arab World. It will analyse in detail the concept, definitions, background, and types of MOOCs (xMOOCs and cMOOCs), as well as the main MOOCs platform in the Western and Arab worlds, and a timeline of the development of MOOCs. It will then observe the status of MOOCs in the developed world, opportunities in the Middle East, and the influence of Western MOOCs on the Arab world, from many perspectives, e.g. educational, religious, cultural and social.
\end{abstract}

Keywords: Online learning, MOOC, Massive Open Online Course, background, the Arab world, aspects of MOOCs

\section{Introduction}

In highlighting how successful the Internet has been in education, John Chambers, CEO of Cisco Systems 2000, stated that "The next big killer application for the internet is going to be education. Education over the internet is going to be so big, it is going to make email usage look like a rounding error" (Alexander, 2001).

Online learning is becoming one of the most significant technological developments as we move further into the $21^{\text {st }}$ century. As part of these developments, a number of innovations that were once simply ideas are now becoming a reality. One of these is the concept of the Massive Open Online Course (MOOC). MOOCs build on the dynamic engagement of hundreds to thousands of students who self-organise their involvement according to learning skills, objectives, previous knowledge, and their shared interests (McAuley et al., 2010).

Within the last few years, online learning has started to take root in the Middle East as a way of addressing some obstacles which have delayed traditional forms of education. The education systems in this zone have been motivated by online learning prospects around the world.

In 2012, MOOCs had a major revolution in the Western world and in 2013, MOOCs started to appear in a few countries in the Middle East. They are continuing to progress into a more widespread form of educational technology (Subbian, 2013).

However, to what extent can these work and what are the motives for applying this new technology to the Arab world? This paper will critically review available literature concerning the status of MOOCs in the Arab world which consists of the 21 Arabic-speaking countries from 
North Africa to the Arabian Gulf, where the Arabic is first language. In this review paper, the target countries are located in the eastern part of the Middle East, which includes the Kingdom of Saudi Arabia, Egypt, Jordan, Lebanon, and Palestine. These were in fact the first countries to launch MOOC platforms in the Middle East back in 2013.

First, we will present some of the most important and widely used definitions of MOOCs, the different types of MOOCs, and then the main MOOC platforms in both the Western and the Arab worlds. Finally, analyse the influence of MOOCs from the Western world on the Arab world.

\section{MOOCs as a Distance Education Method}

\section{Understanding the Concept of MOOCs}

MOOCs have three important attributes. Firstly they are "massive", which refers to the number of students and activities on such courses. Secondly, they are "open" because generally speaking, the software is open-source; the sources of information are open; registration is open to anyone, and, the curriculum assessment processes and students are generally open to a range of different learning environments. Finally, they are online courses that anyone can access if they have an Internet connection, through which they can easily download the course material if required (Masters, 2011).

MOOCs are a recent development in the field of online learning as a method of distance education, and an advancement of the kind of open education ideals proposed by open educational resources (OER) (McAuley et al., 2010).

\section{Definitions of MOOCs}

It is difficult to find a specific definition for a MOOC. One common definition adopted in this paper is the "integration of the connectivity of social networking, the facilitation of an acknowledged expert in a field of study, and a collection of freely accessible online resources" (McAuley et al., 2010).

Moreover, MOOCs as online courses have been described by (O'Prey, 2013) as free courses, offered to a large number of learners at once, and conducted via video lectures and online assignments and exams. Another definition of a MOOC is an "online course which can be attended by a large number of participants, has a defined duration (4-10 weeks) and follows certain pedagogy"; for example, in every first week, the learner will spend it understanding the content of the course and the end of each week is usually for submission of assignments or assessments. In addition, learners will need to dedicate 2 to 6 hours/week on average, depending on their interest or skill level, in order to complete the course successfully (Taneja \& Goel, 2014).

In one report, The European Commission defines a MOOC as "an online course open to anyone without restrictions (free of charge and without a limit to attendance), usually structured around a set of learning goals in an area of study, which often runs over a specific period of time (with a beginning and end date) on an online platform which allows interactive possibilities (between peers or between students and instructors) that facilitate the creation of a learning community. As it is the case for any online course, it provides some course materials and (self) assessment tools for independent studying" (European Commission, 2014). 


\section{Background to the Massive Open Online Course}

Massive Open Online Courses (MOOCs) generated an important revolution in online education by presenting web-based courses free to anyone, anywhere with access to an internet connection. In 2012, MOOCs gained substantial attention from media, students, teachers, and industrialists. They are continuing to progress into a more widespread educational technology (Subbian, 2013).

Otherwise, Michael Gaebel indicated that MOOCs actually did not appear in 2012, but that they were emerging successfully since their establishment in 2008 by Siemens and Downes, with the purpose of improving the learning experience, not least to deliver more learning opportunities (Gaebel, 2013).

In 2008, MOOCs were named and defined because of a new initiative by the leaders George Siemens and Stephen Downes. 'Connectivism \& Connective Knowledge' was their first course clearly designed according to the principles of Connectivism. Because of its size, it was termed a massive open online course and approximately 2200 participants were enrolled (Downes, 2008).

MOOCs may possibly start a new generation in distance education. Clearly they endorse a new model of distance learning. The University of Edinburgh's report in 2013 identified that the recent explosion in university courses that were created by MOOCs offer some turning points in distance education (Davis et al., 2013).

Despite the rapid growth of MOOCs, there are early indicators that this 'boom' is slowing down because there are some questions that have not yet been answered. For instance, how should a university participate in a MOOC initiative? What kind of organisation, student and academic support is needed? How should assessment be organised? How to assure quality? (Rajabi \& Virkus, 2013).

Moreover, MOOCs come in for great challenges of the high dropout rates amongst participants with only a small number finished the course. A related problem that some MOOCs participants are taking the course without the direct presence of a classroom full of students could be also one of the significant limitations of MOOCs flexibility (Eisenberg \& Fischer, 2014).

Overall, Downes believes that there are some criticisms, such as those MOOCs can replace tutors with technology, and the social and personal aspects of learning could be lost. However, it is essential for MOOC learners to be self-motivated and academically ready (Downes, 2013b).

\section{Types of MOOCs (cMOOCs and xMOOCs)}

According to (Siemens, 2012), there are two separate types of online courses sharing the "MOOC" name, and he offered new terms to differentiate them: cMOOCs and xMOOCs.

Connectivist MOOCs (cMOOCs), for instance Peer 2 Peer University, are based on the interaction with objects created by the students in the context of teaching communities (Siemens, 2012).

In 2008 Siemens and Downes developed cMOOCs, which are the first type that focused on knowledge creation and have a different educational philosophy from xMOOCs. The cMOOC model highlights creation, creativity and social networking learning (Siemens \& Baker, 2012), with a focus on knowledge creation and generation (Gaebel, 2013).

The (xMOOCs), e.g. edX, Coursera and Udacity, contain a guided structure of content delivery and traditional interaction of the users. The xMOOCs are the new type of MOOCs that transfer a traditional university learning model into an online learning space. The xMOOC model 
highlights traditional learning approaches through video presentations, short quizzes and testing with a focus on knowledge duplication (Gaebel, 2013).

In an interview with Downes in October 2013, he stated that "The xMOOC is centralized and the cMOOC is distributed. $\mathrm{xMOOC}$ has a core content that everyone follows, while the cMOOC has a wide ranging network of content which people browse through and sample according to their own interests" (Downes, 2013a).

On the other hand, cMOOC has a limited curriculum and set of tasks for their students to accomplish, however, structure and outlines of topics are usually present, but the class activities are not pre-set (Saadatmand \& Kumpulainen, 2014). xMOOCs have obvious problem for using dated pedagogics based on the transmission of content the (knowledge transmission model) (Larry, 2012).

Overall, (Bayne \& Ross, 2014) argued that MOOCs have adopted multiple pedagogic forms where MOOC pedagogy in terms of a cMOOC and xMOOC binary is no longer representative or useful.

\section{MOOC Platforms in the Western World}

This central idea of providing a knowledge platform to anyone, anytime, and anywhere, makes MOOCs a powerful learning technology (Subbian, 2013)

The following table shows differences and similarities between some of the most active companies and universities' MOOCs platforms around the world.

Table 1: MOOCs platforms around the world

\begin{tabular}{|c|c|c|}
\hline Platforms & Differences & Similarities \\
\hline \multirow[t]{3}{*}{$\mathrm{EdX}$} & Governed by Harvard University and MIT & Not for-profit \\
\hline & $\begin{array}{l}\text { Open platform seeks to enable open access to } \\
\text { quality education }\end{array}$ & Established in 2012 \\
\hline & EdX is a combination of MITx and HarvardX courses & Smart phone App \\
\hline \multirow[t]{3}{*}{ Udacity } & $\begin{array}{l}\text { Cofounded by a Stanford professor, who started to } \\
\text { offer information science courses online }\end{array}$ & A for-profit company \\
\hline & Does not have a university partner & Established in 2012 \\
\hline & & Smart phone App \\
\hline \multirow[t]{3}{*}{ Coursera } & $\begin{array}{l}\text { A social entrepreneurship company, that partner } \\
\text { with the top universities in the world }\end{array}$ & A for-profit company \\
\hline & $\begin{array}{l}\text { It was established by two computer science } \\
\text { professors from Stanford University- Daphne Koller } \\
\text { and Andrew NG }\end{array}$ & Established in 2012 \\
\hline & & Smart phone App \\
\hline \multirow[t]{2}{*}{ FutureLearn } & $\begin{array}{l}\text { Includes four non-university partners: the British } \\
\text { Museum, the British Council, the British Library and } \\
\text { the National Film and Television School }\end{array}$ & $\begin{array}{l}\text { A company financed and } \\
\text { owned by The Open University, } \\
\text { UK }\end{array}$ \\
\hline & $\begin{array}{l}\text { Courses from leading UK Universities and some are } \\
\text { outside UK e.g. University of Cape Town }\end{array}$ & Established in late 2012 \\
\hline \multirow[t]{2}{*}{ Iversity } & $\begin{array}{l}\text { European-based online education platform. by co- } \\
\text { founders Jonas Liepmann and Hannes Klöpper }\end{array}$ & Established in October 2013 \\
\hline & $\begin{array}{l}\text { Iversity is the only MOOC platform offering courses } \\
\text { with ECTS-integration }\end{array}$ & \\
\hline
\end{tabular}


MOOCs as a Method of Distance Education in the Arab World - A Review Paper Raniah Samir Adham [r.s.a.adham@pgr.reading.ac.uk], Karsten Oster Lundqvist.

\section{MOOC Platforms in the Arab world}

In an effort to deliver world-class and quality education in the Arab world to millions of Arabicspeaking students, academics, and employers around the globe, a couple of not-for-profit Arab platforms (MOOCs) have been launched in 2013 (Sawahel, 2014).

The following table shows the differences and similarities between most of the known MOOCs platforms in the Arab world.

Table 2: MOOC platforms in the Arab world

\begin{tabular}{|l|l|l|}
\hline Platforms & Differences & Similarities \\
\hline Edraak (Jordan) & $\begin{array}{l}\text { The first Massive Open Online Course portal } \\
\text { for the Arab world }\end{array}$ & Offered at no cost \\
\cline { 2 - 3 } & $\begin{array}{l}\text { Spearheaded by leaders of the country of } \\
\text { Jordan Queen Rania }\end{array}$ & Launched in 2013 \\
\cline { 2 - 3 } & $\begin{array}{l}\text { Powered by open source platform edX, the } \\
\text { Cambridge-based collaborative education by } \\
\text { Harvard University and MIT }\end{array}$ & $\begin{array}{l}\text { Arabic translations of selected } \\
\text { courses }\end{array}$ \\
\hline \multirow{2}{*}{$\begin{array}{l}\text { Rwaq (Saudi } \\
\text { Arabia) }\end{array}$} & $\begin{array}{l}\text { Build an online courseware for the Middle } \\
\text { East }\end{array}$ & Offered at no cost \\
\cline { 2 - 3 } & $\begin{array}{l}\text { Established by two Saudi business men Fouad } \\
\text { Al-Farhan and Sami Al-Hussayen }\end{array}$ & Launched in 2013 \\
\cline { 2 - 3 } & $\begin{array}{l}\text { Gathered experts in the creative community } \\
\text { to offer original courses on a range of topics } \\
\text { from social media, marketing to Lebanese } \\
\text { cooking }\end{array}$ & Offered at no cost \\
\cline { 2 - 3 } & Open to Arab world including North Africa & Launched in 2013 \\
\cline { 2 - 3 } & $\begin{array}{l}\text { SkillAcademy (formerly Eduudle) offers over } \\
10,000 \text { online courses }\end{array}$ & Offered at no cost \\
\cline { 2 - 3 } & Offers skill-camps built for specific skillsets & Launched in 2013 \\
\cline { 2 - 3 } & & English Language \\
\hline \multirow{2}{*}{$\begin{array}{l}\text { SkillAcademy } \\
\text { (Egypt) }\end{array}$} & & \\
\hline
\end{tabular}




\section{Timeline of MOOC Developments}

\begin{tabular}{|c|c|c|c|c|c|c|}
\hline \multicolumn{2}{|c|}{ From 2000} & To 2007 & 2008 & $\begin{array}{c}2009 \\
- \\
2010\end{array}$ & 2012 & 2013 \\
\hline \multicolumn{7}{|c|}{$\begin{array}{l}\text { Open } \\
\text { Education }\end{array}$} \\
\hline \multicolumn{2}{|c|}{$\begin{array}{l}\text { Open } \\
\text { Education } \\
\text { Resources }\end{array}$} & $\downarrow$ & $\begin{array}{l}\text { Connectivist } \\
\text { MOOC } \\
\text { (cMOOCs) }\end{array}$ & & & $\begin{array}{c}\text { Rwaq } \\
\text { (Saudi Arabia) }\end{array}$ \\
\hline$\uparrow$ & & $\begin{array}{c}\text { ITunes U Khan } \\
\text { Academy }\end{array}$ & & & $\longrightarrow$ Udacity & $\begin{array}{l}\text { SkillAcademy } \\
\text { (Egypt) }\end{array}$ \\
\hline & & $\begin{array}{l}\text { Open } \\
\text { Source } \\
\text { Software }\end{array}$ & & $\rightarrow$ & $\begin{array}{l}\text { Stanford } \\
\mathrm{xMOOCs} \rightarrow \text { Coursera }\end{array}$ & $\begin{array}{l}\text { MenaVersity } \\
\text { (Lebanon) }\end{array}$ \\
\hline \multirow[t]{3}{*}{$\begin{array}{l}\text { Open } \\
\text { Content }\end{array}$} & & $\begin{array}{l}\text { earning } \\
\text { anagement systems }\end{array}$ & & & & Edraak (Jordan) \\
\hline & $\begin{array}{l}\text { MIT } \\
\text { Cour: } \\
\text { Cons }\end{array}$ & $\begin{array}{l}\text { pen } \\
\text { vare } \\
\text { ium }\end{array}$ & & & $\rightarrow$ MITx edX & \\
\hline & $\begin{array}{l}\text { Open } \\
\text { Open }\end{array}$ & versity- & & & $\rightarrow \mathrm{Fu}$ & $\begin{array}{l}\text { Learn } \\
\text { K) }\end{array}$ \\
\hline
\end{tabular}

Figure 1. Timeline of MOOC developments. Adapted from (O'Prey, 2013) Massive Open Online Course, Higher Education Digital Moments

The above Figure illustrates the rapid development in MOOCs since 2008. In 2011, Stanford's Professor Siemens established potential xMOOCs courses at a low cost. In 2012, as independent, for profit technology initiatives Udacity, Coursera, MITx, EdX and FutureLearn were launched (O'Prey, 2013). In addition, in 2013, some platforms in the Arab world were established, such as Edraak, Rwaq, MenaVersity and SkillAcademy, which were added to the Figure by the researcher.

\section{MOOCs in Europe}

A systematic study of the literature from 2008-2012 showed that a large majority of MOOC participants are from North America and Europe (Liyanagunawardena, et al., 2013).

In fact, MOOCs seem to be spread all over Europe, most often in the highest revolution. For instance, OPenupEd provides a portal pointing to various academic MOOCs for higher education. The University of Amsterdam offers its MOOC with Sakai OAE, while Leiden has launched with Coursera and, Delft chose edX. In Germany, 10 MOOCs have been built up e.g. Iversity and Coursera for TU Munich. Spain's MOOCs have joined under the umbrella of (Miriada) with the support of some private companies involved with Spanish speaking South America (Epelboin, 2013). Likewise, in Denmark, eight universities are developing MOOCs and, the University of Copenhagen negotiating with Coursera. In Italy, Sapienza has joined Coursera and, in the UK, there is FutureLearn. Last but not least, in France, the Ministry of Higher Education launched the 2013 "FUN" France Universite Numerique (Brahimi \& Sarirete, 2015).

Overall, only the UK has announced a national consortium, using the technology to make university courses open and flexible, in order to attract more students, both nationally and internationally. The choice in the other European countries will be between US and regional or 
national consortia. This will depend on national culture and the Higher Education concerned, because the main universities associations have not yet defined their policy and, it seems that a European consortium will not be here any time soon (Epelboin, 2013).

\section{The Impact of MOOCs in Higher Education}

Dan Greenstein, director of postsecondary education at the Bill and Melinda Gates Foundation and a major funder of the MOOC experiment, was questioned by reporters as to whether there is a clear strategy motivating MOOCs in Higher Education. He stated that without a doubt that MOOCs could help to solve many problems (Kendrick \& Gashurov, 2013).

New approaches for Higher Education establishments have generated important interest from governments, institutions and commercial organisations. The recent value offers for institutions to participate in MOOCs are recognised as "education access, experimentation and brand extension" (Epelboin, 2013).

The MOOC phenomenon is therefore in progress and, it could change teaching approaches in Higher Education. However, it will not necessarily threaten traditional methods of teaching. Moreover, MOOCs could be a useful solution for the shortage of university places, especially in the developing world (McAuley et al., 2010).

On the other hand, it has been argued that MOOCs will not provide the opportunity for students to gain world class educational experience, although many of the courses are offered by prestigious universities, e.g. Harvard and Stanford. However, participant statistics from several MOOC platforms indicate that the large majority of students on these courses already have university degrees (Yuan et al., 2013).

\section{The Status of MOOCs in the Arab World}

\section{The Impact of MOOCs from the Perspectives of Developing Countries'}

As 2013 saw EdX, Coursera, and Udacity grow in importance, 2014 has been the year of the MOOC in the Middle East. However the overload of sources, educational knowledge and economic, social and cultural aspects of MOOCs might be considered a huge challenge for learners from developing countries, including the Arabic-speaking countries; for instance, it could be very difficult for learners to participate in MOOC platforms because of a poor Internet connection, especially in small towns and rural areas in the region.

Furthermore, access to new technology in education requires good computer skills which are still in their infancy in developing countries. The majority of MOOC content is also in English and that could limit access for learners from such countries, as a lower percentage of the population will have experienced the English language to the level needed to take an online course on a MOOC. Most students in developing countries mainly use their local language and only a small proportion of the population is multilingual (Liyanagunawardena et al., 2013).

(Brahimi \& Sarirete, 2015) argue that in the Arab world MOOCs has the potential to be part of a positive influence on the traditional higher education system. However, it's too soon to say if MOOCs represent a substitute for traditional courses.

\section{Opportunities in the Middle East}

Bearing in mind the significant language barrier, with no Arab university ranked amongst the top universities globally and employers complaining about a major skills gap, Dakkak, manager of Edraak stated that "MOOCs have the potential to be a reasonable solution that could bring a 
better quality in higher education to many of the Arabic learners around the world" (Dakkak, 2013).

Moreover, Anant Agarwal, chief executive of edX, explained in an interview with The National, that there are many participants from the Arab world taking courses on edX and so, there is a high awareness that the materials needs to be translated and courses should be offered in Arabic language (Everington, 2013).

According to Deloitte's technology, media and telecommunications (TMT) annual prediction report for the Middle-Eastern region, awareness of MOOCs has increased and Arabic MOOCs are expected to gain power this year. MOOC platforms like Edraak, Rwaq and MenaVersity have had a warm reception from the population (Lee et al., 2014).

On the other hand, MOOCs as a new technology could help students with free online courses related to their subjects, in order to reduce the amount of money spent on private tutoring services, which is a common issue for families in Saudi Arabia, UAE and Egypt. In general, MOOCs would be a transformative change to current education and Higher Education institutions (Brahimi \& Sarirete, 2015).

No consortium for Arabic platforms exists, like FutureLearn or Coursera. However, Mr AlFarhan declared that "Rwaq are currently in talks with five universities interested in licensing the Rwaq platforms to launch their own online education initiatives" (Omran, 2013).

\section{Edraak MOOCs Platform (Jordan)}

Downes states that MOOCs will play a significant role in the future; "MOOCs are being presented by various providers and have become a global phenomenon, with the launch of Britain's FutureLearn and the first Arabic MOOCs (Edraak) coming online" (Downes, 2013b).

The rising phenomenon of MOOCs is no longer limited to the English language. EdX has partnered with The Queen Rania Foundation for Education and Development in Jordan and is offering Arabic language MOOCs, to serve a large number of Arabic-speaking students. Edraak was launched on 19 May, 2013 as the first Arabic MOOC platform.

Samir Abdel-Aal, Professor of Genetics and Molecular Biology at the National Research Centre in Cairo, told the University World News that Edraak will take out the language barrier and, improve higher education access by encouraging online learning and decreasing the knowledge gap between the Arab world and developed countries (Sawahel, 2014).

In addition, Edraak's manager declared that Edraak presented a number of English language MOOCs for non-Arabic speaking learners, thus allowing Arabic professors to describe their personal experience of Edraak platforms to the Western world (Pirkle, 2014).

On the other hand, some challenges have also been presented by Edraak; for example there have been technological issues for some of the registered participants as regards their Internet connection, in that there was insufficient bandwidth to download and stream MOOC lectures. In response to this issue, the Edraak team is trying to communicate with community-based technical centres, where learners can access the Internet on the correct bandwidth free of charge. Another challenge concerns raising greater awareness of what MOOCs are and, how they are used, creating a sustainability model so that Edraak can remain effective (Pirkle, 2014). 


\section{Rwaq MOOCs Platform (Saudi Arabia)}

Arabic is one of the top six languages of the United Nations and is the mother tongue of more than 350 million people. "It is the 7th most used language on the internet after English, Chinese, Spanish, Japanese, Portuguese and German" (Sawahel, 2014).

To serve this large Arab speaking community, Rwaq was launched in September 2013 as a platform for MOOCs. It offers free academic courses on social media, art, psychology, medicine, engineering and religion in an attractive and simple interface. Rwaq means "gallery" in Arabic, so the name is a nod to the galleries of the most prominent mosques in the Muslim world, where learners used to gather in circles around instructors to study different sciences (Curley, 2013).

Moreover, Rwaq co-founder Fouad Al-Farhan stated that MOOCs could improve education systems in the Arab world and set a new bar for skills training programmes. Due to the low quality of training in Saudi Arabia, many employees embark on MOOCs for a certificate. Therefore, Rwaq is trying to introduce high quality academic content from qualified professors and professionals with practical experience. "Rwaq is on its way to becoming a regional hub for e-learning in the Middle East" (Curley, 2013).

However, Rwaq has also been criticised for its low completion rates, and most providers acknowledge that fewer than $10 \%$ of students finish the course. Rwaq's founders are inspired by MOOC developments. However they are not involved in it as a business model, but are rather "trying to find the correct business model which will work in the Arab world by assisting others to create their own initiatives" (Curley, 2013).

According to (Brahimi \& Sarirete, 2015), the total number of courses may be counted by looking at MOOC providers' websites and observing a list of the courses. As a result, there is a positive trend towards Rwaq, with 34 free courses (3.4\%), which exceeds the number offered by Iversity $(3.1 \%)$ and approached the number offered by FUN $(3.8 \%)$.

In December 2014, Rwaq presented a new platform for the healthcare sector, called 'Junnah'. This offers online scientific training programmes on how to avoid or deal with common diseases in the Arab world. It automatically observes the activities of users through smart devices which could allow experiences and inspiration to be exchanged (Ayad, 2015a).

At the beginning of 2015, Rwaq launched another MOOC platform called 'Maharah'. It focuses on skills training, project management, network management, and operating systems etc. with the aim of creating a community of educators in the Arab world (Ayad, 2015b).

\section{MenaVersity (Lebanon)}

In September 2013, Hassan Kanj, a computer science specialist from Lebanon, together with a colleague, Firas Wazneh, created the MOOC platform MenaVersity, which offers open online courses in Arabic. Kanj explained that MenaVersity targets the Middle East and North Africa and is similar to many other MOOC programmes around the world, offering original courses in subjects such as social media, marketing and famous Lebanese cuisine. It also provides private tutoring and counselling sessions, linking users with professionals. The content offered appeals mainly to the 16 to 40 age group (Topalian, 2013).

\section{SkillAcademy (Egypt)}

Paul Lee, global TMT leader at Deloitte, stated that SkillAcademy is one of the most interesting MOOC platforms in the region. It is an advanced level and is based in Egypt. It combines all that 
is available around the world in the domain of online learning and has more than eight million users (Hamid, 2014).

SkillAcademy was launched in 2013 and one of its co-founders, Bassem Fayek, explained to 'ScoopEmpire' in March 2014 that SkillAcademy runs free online courses through which you can learn anywhere and, at any time from the world's top universities, e.g. Stanford, Harvard, edX, MITx, etc. in English, with no translation and students can receive a certificate on completion of the course and its assignments. In addition, they are provided with a verification code so their certificate can be authenticated for their employer (Muscara, 2014).

In addition, SkillAcademy courses are bundled into 'skill-camps', which are a combination of courses focused on a specific skill-set needed in the job market, in order to develop very high impact training programmes to progress participant's careers. They also, cater for those who want to change their career and are looking for relevant coursework to help them acquire new skills.

Overall, SkillAcademy faces some challenges with participants, as self-education requires a great deal of self-discipline, without which students may easily be led to drop out from the course (Muscara, 2014).

Dina Kiwan, Associate Professor of Sociology at the American University of Beirut (AUB) and an expert on citizenship studies, stated "there is an urgent need for the Arab region to develop its capacities for learners' needs and open the routes to higher education and vocational training by developing an accessible flexible system and approach for lifelong learning” (AUB, 2014).

As awareness of MOOCs is raised in the region, there will be a greater demand for more local versions. The following sections describe the new MOOC platforms launched in 2014 and which are still being piloted.

\section{The Ministry of Labour MOOC Platform}

In September 2014, the Ministry of Labour in Saudi Arabia, in cooperation with edX, announced the launch of an open-platform MOOC aimed at bridging the gap between education and employment in Saudi Arabia and throughout the Arab world. The courses are expected to begin with a pilot programme targeting Saudi women, people with disabilities and those from rural communities, helping them to acquire the necessary skills to secure a job.

Moreover, it will offer courses from edX university lecturers, translated into Arabic, and original courses developed from scratch in Arabic. To date, however, there is no mention of the name of the MOOC portal or URL (Primo, 2014).

Maha Taibah, Advisor to the Ministry of Labour on Human Capital Development, explained to the Saudi Gazette (Ba-Isa, 2014) that in Saudi Arabia the private sector is growing quickly and employees need to upgrade their skills to meet rising demands. Moreover, women and the younger generations need to have access to high quality career training in areas such as IT, healthcare, retail and manufacturing. The initiative is to produce more job opportunities and economic authorisation throughout the Arab world, as well as in Saudi Arabia.

\section{An-Najah National University MOOC}

In October 2014, Professor Maher Natsheh, Acting President of An-Najah National University in Palestine, in a press conference, announced the launch of the first free English-language MOOC in the zone, entitled 'Discover Palestine', presenting Palestine's history, archaeology and culture to people around the world. The course addresses the international public and draws attention to the Palestinian cause. Moreover, the course was designed by the e-Learning Centre, 
with the contribution of specialists from the University. Around 100 people have participated in the pilot phase from various countries around the world, e.g. France, Spain, America, Malaysia, and India (An-Najah National University, 2014).

\section{American University of Beirut MOOC}

In the autumn semester of 2014, AUB launched a MOOC created by some AUB faculty members, with the goal of providing the best solution for those seeking educational opportunities, who live in regions where there is political instability and for those experiencing socio-economic difficulties (AUB, 2014).

Zane Sinno, coordinator for the Communications Skills programme in the AUB English Department declared, "I am expecting anywhere between 2,000 to 3,000 registered students when the course starts on October 8, 2014" (AUB, 2014).

A pilot MOOC course was previously offered in the summer of 2014 by AUB and in agreement with the Edraak MOOC platform, which allowed AUB to provide the instructors and design the course, with Edraak providing the appropriate MOOC platform. Throughout the upcoming autumn course, AUB will be able to evaluate the experience and decide whether to expand the programme and include courses from other faculties (AUB, 2014).

\section{The Influence of MOOCs from the Western World on the Arab World}

This year, MOOCs will gain power across the Arab World according, to Deloitte's (TMT) predictions for the region. As stated above, the most widely accessed MOOCs in the Middle Eastern region are, Edraak (Jordan), Rwaq (Saudi Arabia), MenaVersity (Lebanon), SkillAcademy (Egypt), Ministry of Labor (Saudi Arabia), An-Najah National University (Palestine), and American University of Beirut (AUB) (Lebanon). There are in fact several reasons why these Arab countries have launched their own platforms and these will be examined below.

\section{Inspiration}

The inspiration for MOOCs in the Arabic region mainly came from some of the top universities in the Western world, e.g. Harvard, MIT, Stanford, etc. and the aim was to bring a higher quality of education to Arabic learners, especially to the high number of learners amongst the Arabic population who participate in these MOOC platforms.

Edraak, the Ministry of Labour and SkillAcademy are some of the Arabic MOOCs motivated by international models. They have displayed entrepreneurship, and the edX MOOC platforms offer a means of delivering high quality online education as well as reducing the digital and, general knowledge gap, and language barrier between the Arab world and developed countries. On the other hand, the Saudi Rwaq platform was inspired by the MOOC movement, but not devoted to its business model. The Rwaq team have stated that they will try to find the right business model for the Arab world, in order to build a star platform to offer the region fully native content from local professors and a fully Arabic MOOC platform (Curley, 2013).

\section{The Need for MOOCs in the Arab World}

There are many reasons MOOCs are needed in the Arab World; the growing population, the education system with overcrowded classrooms, expensive private universities, the lack of resources for meaningful development, a shortage of teaching staff, and people in remote areas who cannot travel to university daily in some of the developed countries (see Table 3). 


\section{Language}

Most of the platforms found above are targeted at the Arabic language population and some are completely in Arabic, like Rwaq and MenaVersity. Edraak have both edX English courses translated into Arabic, and some local professors presenting Arabic courses in English to deliver their experience to the non-Arab audience. Similarly, the Ministry of Labour's MOOC is translated into Arabic from edX. Alternatively, SkillAcademy, AUB and An-Najah present in English, but have plans to translate all their MOOCs into Arabic. Moreover, we can see that the cultural aspect is clear in An-Najah's MOOC, 'Discover Palestine' as they have tried to deliver a message to the Western population by presenting in English (see Table 3).

\section{The Quality of Education}

There are three types of courses: academic, non-academic and skills training courses. Edraak and Rwaq, for example, run all three types of course mentioned above. However, AUB and An-Najah are piloting MOOCs under educational institutions and produce only one type of course.

SkillAcademy targets companies and employees who cannot find a job in Egypt, due to their lack of skills and, so SkillAcademy produce skills training courses. The Ministry of Labour has a similar aim but the focus is more on women and disabled people. However, MenaVersity is not an educational platform, but is limited to certain topics; for example Lebanese cooking. MenaVersity also run courses for recent graduates seeking to enter the job market. However, Western MOOCs may be perceived to be of better quality, because most of the courses are delivered from prestigious universities around the world (see Table 3).

\section{Gender Segregation}

Due to cultural, social and religious reasons in some Arab countries, learning opportunities for females are limited because of gender segregation. Males and females cannot meet or communicate freely anywhere they want (Tubaishat et al., 2006).

Saudi Arabia is one such, country that strictly enforces gender segregation and so, a pilot MOOC platform has been launched under the Ministry of Labour, especially for women. Generally, the author believes that MOOCs can help remove these cultural and social limitations and, that the social aspect should not be neglected. MOOCs can enable freedom of expression for women so they can communicate in a real world setting (mixed gender classes) meeting and interacting with others.

\section{Credentials}

Most MOOCs are free of charge and some offer certificates after completing courses, except MenaVersity which does not offer certificates to learners, as it is not a university website. Udacity and some other MOOCs charge a fee for the certificate.

\section{Accessibility}

The instructional design of most Arabic MOOCs is simple, making them easy to access. It is easy to register with the respective websites and the material is presented in a simple format. Rwaq is the only platform that has launched a smartphone application which has a similar design to their website. In addition, MenaVersity is planning to launch smartphones applications. In contrast, most of the Western MOOCs already have live smart-phone applications, e.g. edX, Coursera, Udacity and Khan Academy (see Table 3).

The following table shows the 7 themes of MOOCs in the Arab World, in relation to their main aspects. 
MOOCs as a Method of Distance Education in the Arab World - A Review Paper Raniah Samir Adham [r.s.a.adham@pgr.reading.ac.uk], Karsten Oster Lundqvist.

Table 3: The Themes of MOOCs in the Arab World

\begin{tabular}{|c|c|c|c|}
\hline The Themes & Arabic MOOCs & Western MOOCs & The Aspects \\
\hline \multirow[t]{4}{*}{ Inspiration } & SkillAcademy & $\mathrm{EdX}$ & Social \\
\hline & Edraak & Harvard & Cultural aspects \\
\hline & Ministry of Labour & MITx & \\
\hline & & Stanford & \\
\hline \multirow[t]{5}{*}{ The Need for MOOCs } & Expensive universities & $E d X$ & Economic Political \\
\hline & The education system & Harvard & Cultural aspects \\
\hline & Lack of resources & MITx & \\
\hline & Teaching staff shortage & Stanford & \\
\hline & Difficulties in transportation & & \\
\hline \multirow[t]{3}{*}{ Language } & Arabic: Rwaq, MenaVersity & $E d X$ & Social \\
\hline & $\begin{array}{l}\text { English: Skill Academy, AUB, } \\
\text { An-Najah University }\end{array}$ & & Political \\
\hline & $\begin{array}{l}\text { English \& Arabic: Edrakk, } \\
\text { Ministry of Labour }\end{array}$ & & Cultural \\
\hline \multirow[t]{6}{*}{ Quality of Education } & $\begin{array}{l}\text { Academic: Edraak, Rwaq, } \\
\text { AUB, An-Najah }\end{array}$ & $\mathrm{EdX}$ & Social \\
\hline & $\begin{array}{l}\text { Non-Academic: Edraak, Rwaq, } \\
\text { MenaVersity }\end{array}$ & Coursera & Cultural \\
\hline & $\begin{array}{l}\text { Skills Training: Edraak, Rwaq, } \\
\text { Skill Academy, Ministry of } \\
\text { Labour }\end{array}$ & FutureLearn & \\
\hline & & Udacity & \\
\hline & & MITx & \\
\hline & & Khan Academy & \\
\hline \multirow[t]{3}{*}{ Gender Segregation } & Ministry of Labour & - & Social \\
\hline & & & Cultural \\
\hline & & & Religious \\
\hline \multirow[t]{2}{*}{ Credentials } & Certificate: Most platforms & Most platforms & Social aspect \\
\hline & No Certificate: MenaVersity & $\begin{array}{l}\text { Udacity charges for } \\
\text { certificates }\end{array}$ & \\
\hline \multirow[t]{5}{*}{ Accessibility } & $\begin{array}{l}\text { Usability \& Design: Most } \\
\text { platforms }\end{array}$ & Smartphone apps & Social aspect \\
\hline & Smartphone apps: Rwaq & edX & \\
\hline & & Coursera & \\
\hline & & Udacity & \\
\hline & & Khan Academy & \\
\hline
\end{tabular}

\section{Conclusion}

This paper has shown the inspiration of MOOCs from the West for the Arab world. MOOCs are disruptive innovations, and have generated great impact on higher education worldwide. They are delivered via online environments which are free of charge and open to all learners. The influence of Western MOOCs on the Arab world is found in many important aspects: cultural, social, political and economic.

Several issues have been highlighted regarding the status of MOOCs in the Arab World. For instance, the majority of these Arabic MOOCs are launched under private companies, which is likely to limit the courses in terms of quality and content. Another issue to be considered is the 
low rate of participations due to the lack of awareness in the Arab world of what MOOCs really are.

In addition, more work is needed in future to guide professors and leaders in Higher Education institutions throughout the Arab world, so that they will be more aware of the benefits of online learning and MOOCs. There should also be a phased plan for introducing MOOCs to some select classes in universities in Arabic-speaking countries.

Finally, there are a limited number of MOOCs resources in the Arab world and papers to support Arab MOOC initiatives. Future work that will be considered in the main part of my $\mathrm{PhD}$ research is finding out what motivates learners and teachers on MOOCs in Saudi Arabia. The researcher will use a number of instrumental case studies to make comparisons in relation to social, cultural and gender segregation issues in MOOCs in the Saudi Arabian societies, by adopting Avatar technology for female tutors on online courses.

\section{References}

1. Alexander, S. (2001). E-learning developments and experiences. In Education \& Training, 43, (pp. 240-248).

2. An-Najah National University (2014). Press conference: launching the first free English language online course, 'Discover Palestine'. Available: http://www.najah.edu/node/33505 [Accessed 10-102014].

3. AUB, American University of Beirut (2014). AUB tests the waters of open online learning and digital degrees with pilot courses. AUB News. Available: http://aub.edu.lb/news/2014/Pages/moocsonline-learning-digital-degrees.aspx [Accessed 14-1-2015].

4. Ayad, S. (2015a). A new Saudi healthcare app looks to solve the obesity epidemic. In Wamda Blog, February 2, 2015. Available: http://www.wamda.com/2015/02/can-app-tackle-diabetesepidemic-saudi-arabia [Accessed 13-5-2015].

5. Ayad, S. (2015b). Saudi's Rwaq team hope to create community of educators. In Wamda Blog, March 25, 2015. Available: http://www.wamda.com/2015/03/saudi-rwaq-introduces-neweducation-platform [Accessed 13-5-2015].

6. Ba-Isa, M.Y. (2014). Saudi eLearning portal to bridge the gap between education and employment. In Saudi Gazette, August 6, 2014. Available:

http://www.saudigazette.com.sa/index.cfm?method=home.regcon\&contentid=2014080621 3747 [Accessed 20-1-2015].

7. Bayne, S. and Ross, J. (2014). The pedagogy of the Massive Open Online Course: the UK view. The Higher Education Academy (Series Ed.) Recuperado el, 30.

8. Brahimi, T. and Sarirete, A. (2015). Learning outside the classroom through MOOCs. In Computers in Human Behavior, (in press). doi:10.1016/j.chb.2015.03.013. Available: http://www.sciencedirect.com/science/article/pii/S0747563215001995 [Accessed 2-5-2015].

9. Curley, N. (2013). Saudi Arabia's Rwaq builds a online courseware platform for Middle East. In Wamda Blog, December 5, 2013. Available: http://www.wamda.com/2013/12/saudi-arabiarwaq-online-courseware-mooc-middle-east [Accessed 10-9-2014].

10. Dakkak, N. (2013). What are MOOCs, and how can you benefit from them? In Wamda Blog, May 13, 2013. Available: http://www.wamda.com/2013/05/what-are-moocs-what-mean-formiddle-east [Accessed 8-11-204].

11. Davis, H.; Leon, K.D.M.; Vera, M.D.M.S.; White, S. (2013). MOOCs for Universities and Learners, An analysis of motivating factors. 
12. Downes, S. (2008). Places to go: Connectivism \& connective knowledge. In Journal of Online Education, 5.

13. Downes, S. (2013a). Connective Knowledge and Open Resources. In Half an Hour Blog, October 20, 2013. Available: http:/ / halfanhour.blogspot.co.uk/2013/10/connectiveknowledge-and-open-resources.html [Accessed 28-9-2014].

14. Downes, S. (2013b). MOOCs will ultimately play a transformational role. In Half an Hour, Blog, November 6, 2013. Available: http://halfanhour.blogspot.co.uk/2013/11/moocs-willultimately-play.html [Accessed 2-12-2014].

15. Eisenberg, M. and Fischer, G. (2014). MOOCs: A perspective from the learning sciences. Presented at the Learning and Becoming in Practice: $11^{\text {th }}$ International Conference of the Learning Sciences (ICLS).

16. Epelboin, Y. (2013). MOOC in Europe. UPMC-Sorbonne Université.

17. European Commission (2014). Report on Web Skills Survey: Support Services to Foster Web Talent in Europe by Encouraging the use of MOOCs Focused on web Talent - First Interim Report. Available: http://openeducationeuropa.eu/sites/default/files/MOOCs-for-web-skills-survey-report.pdf [Accessed 11-1-2015].

18. Everington, J. (2013). EdX in talks with Mideast schools to host Arabic-language courses. In The National Business Blog, October 24, 2013. Available:

http://www.thenational.ae/business/industry-insights/technology/edx-in-talks-withmideast-schools-to-host-arabic-language-courses [Accessed 8-12-2014].

19. Gaebel, M. (2013). MOOCs-Massive Open Online Courses. EUA Ocassional Papers.

20. Hamid, T. (2014). Massive Open Online Courses make strides across region. In The National - Business, March 19, 2014. Available:

http://www.thenational.ae/business/technology/massive-open-online-courses-make-stridesacross-region [Accessed 7-1-2015].

21. Kendrick, C. and Gashurov, I. (2013). Libraries in the Time of MOOCs. EDUCAUSE.

22. Larry, C. (2012). MOOCs and pedagogy: Teacher-centered, student-centered, and hybrids (Part 1).

23. Lee, P.; Stewart, D. and Parvez, A. (2014). Technology, Media \& Telecommunications Predictions 2014 | Middle East. Deloitte. Available:

https://www2.deloitte.com/content/dam/Deloitte/xe/Documents/technology-mediatelecommunications/predictions2014/dtme_TMT_Predictions2014_TMTPredictions2014.pd f

24. Liyanagunawardena, T.; Williams, S. and Adams, A. (2013). The impact and reach of MOOCs: a developing countries' perspective. eLearning Papers.

25. Masters, K. (2011). A brief guide to understanding MOOCs. In The Internet Journal of Medical Education, 1.

26. McAuley, A.; Stewart, B.; Siemens, G.; Cormier, D. (2010). The MOOC model for digital practice.

27. Muscara, A. (2014). Q\&A: Bassem Fayek, Co-Founder of SkillAcademy.com. In ScoopEmpire, March 3, 2014. Available: http://scoopempire.com/qa-bassem-fayek-co-founderskillacademy-com/ [Accessed 7-1-2015].

28. O’Prey, P. (2013). Massive Open Online Course, Higher Education digital moments? Universitiesuk.

29. Omran, A.A. (2013). Saudi MOOC Startup Wants to "Disrupt" Arab Education. In The Wall Street Journal - Middle East, December 17, 2013. Available: 
http://blogs.wsj.com/middleeast/2013/12/17/ saudi-mooc-startup-wants-to-disrupt-arabeducation/ [Accessed 10-5-2015].

30. Pirkle, H. (2014). Arabic MOOC platform Edraak launches to bring quality education to the region. In Wamda Blog, June 15, 2014. Available: http://www.wamda.com/2014/06/firstarabic-mooc-platform-launches-quality-education [Accessed 3-12-2014].

31. Primo, V. (2014). New E-Learning Portal Promises to Help Saudis Land a Dream Job. In BarakaBits, 09/08/2014. Available: http://www.barakabits.com/2014/08/e-learning-portalbrings-saudis-closer-to-their-dream-job [Accessed 13-1-2015].

32. Rajabi, H. and Virkus, S. (2013). The Potential and Readiness of Tallinn University to Establish Massive Open Online Courses (MOOCs).

33. Saadatmand, M. and Kumpulainen, K. (2014). Participants' perceptions of learning and networking in connectivist MOOCs. In MERLOT Journal of Online Learning and Teaching, 10, (pp. 16-30).

34. Sawahel, W. (2014). New Arab platform for MOOCs launched. In University World News, 30 May, 2014. [Online]. Available:

http:/ / www.universityworldnews.com/article.php?story $=20140529184801359$ \&query $=\mathrm{New}$ + Arab + platform + for + MOOCs+launched [Accessed 7-10-2014].

35. Siemens, G. (2012). MOOCs are really a platform. In Elearnspace Blog, July 25, 2012. Available: http://www.elearnspace.org/blog/2012/07/25/moocs-are-really-a-platform/ [Accessed 610-2014].

36. Siemens, G. and Baker, R.S.J.D. (2012). Learning analytics and educational data mining: towards communication and collaboration. In the Proceedings of the $2^{\text {nd }}$ international conference on learning analytics and knowledge, 2012, (pp. 252-254). ACM.

37. Subbian, V. (2013). Role of MOOCs in integrated STEM education: A learning perspective. In the proceedings of Integrated STEM Education Conference (ISEC), 2013 IEEE, 9 March 2013, (pp. 1-4).

38. Taneja, S., and A. Goel. (2014). MOOC providers and their strategies. In International Journal of Computer Science and Mobile Computing, 3(5), (pp. 222-228).

39. Topalian, N. (2013). Lebanese developers to launch online learning app, in Arabic. In AlShorfa, September 27, 2013. Available: http://alshorfa.com/en_GB/articles/meii/features/2013/09/27/feature-02 [Accessed 6-1-2015].

40. Tubaishat, A.; Bhatti, A.; El-Qawasmeh, E. (2006). ICT experiences in two different Middle Eastern universities. In Issues in Informing Science and Information Technology, 3, (pp. 667-678).

41. Yuan, L.; Powell, S. and Cetis, J. (2013). MOOCs and open education: Implications for higher education. Cetis White Paper.

\section{Acknowledgments}

I would like to acknowledge the support of the Saudi government who gave me the opportunity to study at the University of Reading. I would also like to thank Dr. Tharindu Liyanagunawardena for her feedback and invaluable comments on an earlier version of this paper. 